\title{
CHIMNEY RESERVOIRS: UNIQUE TECHNICAL STRUCTURES FROM THE FIRST HALF OF THE 20TH CENTURY IN THE CZECH REPUBLIC
}

\author{
MARTIN VONKA ${ }^{a, *}$, RoBert KořínEK ${ }^{b}$ \\ ${ }^{a}$ Faculty of Civil Engineering CTU in Prague, Thákurova 7/2077, 16629 Prague, Czech Republic \\ ${ }^{b}$ T. G. Masaryk Water Research Institute, public research institution, branch Ostrava, Macharova 5, 71000 \\ Ostrava, Czech Republic \\ * corresponding author: martin.vonka@fsv.cvut.cz
}

\begin{abstract}
In the past, various methods and technological systems were used to supply water on industrial and other sites. In the early 19th century, Professor Otto Intze invented a new form of water reservoir that could be installed in a tower tank or even on the body of a chimney. This gave rise to a structure that had never been seen before - a chimney reservoir. The advantages of this structure resulted in it quickly becoming very popular, especially in the country in which it originated, Germany.

The structure spread from the German Empire into other countries, including Austria-Hungary. The first chimney reservoir on the Czech territory originated in the late 19th century, the last structure of this type was built in 1962. Although their history was short, more than sixty distinctive structures of this kind were built in the Czech lands, the twenty-one of which that have survived to the present day can be described as a unique industrial heritage.

This article outlines the origin and evolution of different types of chimney reservoirs and describes the structural and technological designs used for such structures on the territory of what is now known as the Czech Republic.
\end{abstract}

KEYwORDS: factory chimneys; water reservoir; industry; heritage; Otto Intze; landmark; concrete structures.

\section{INTRODUCTION}

Industrial structures, factory chimneys included, are slowly coming to be a respected part of our cultural heritage. It is this that is leading to more and more questions being raised about the value and qualities of these structures and about what new uses they can be put to, how to approach them, and how to integrate them with the existing structural environment [1 4].

A specific subgroup of technical structures and of chimneys in particular is factory chimneys with water reservoirs. They combine the function of a factory chimney, drawing off the unwanted fumes produced in technological production processes, and the function of a water tower, providing sufficient pressure for the water supply system to operate and enough water for use in the various functions of the factory.

These chimney reservoirs have yet to be a subject of a systematic structural and technical research in the Czech Republic. Nor are there any known studies or publications on this subject internationally. There are, however, works that have been published in various countries focusing on ordinary factory chimneys for example, the publications by James Douet [5] or Gracia López Patiño et al. 6] Among current Czech studies devoted to notable Czech factory chimneys and their conversion to a new use, it is possible to cite the monograph by Martin Vonka [7].

In the Czech Republic, factory chimneys, like indus- trial heritage in general, are of a marginal interest, or at best are lost amidst historical descriptions of large industrial enterprises. Historian Jaroslav Jásek [8, 9] has produced basic descriptions of some chimney water towers in Prague, additional information can be found in the database of the Water Tower Association, the Fabriky.cz portal and in the vast KODA database of chimneys maintained by the Union of Czech Chimney Climbers.

Not much has been published on the technical designs of chimney reservoirs in Czech literature - in 1906, a brief introduction to chimney water towers was written by František Klokner, a populariser of chimneys and future rector of the Czech Technical University in Prague [10]. In 1919, a monograph on water supply technology was written by a prominent Czech specialist in the subject Jan Vladimír Hráský [11], while Karel Válek specialised in the statics calculations for building reinforced concrete reservoirs, published several papers on the subject [12] and in 1920 defended his dissertation on this topic.

The most comprehensive, albeit brief, treatment of the subject of chimney reservoirs was published by Rudolf Kukač in 1920 [13]. In 1923, reservoirs on chimneys were the subject of a short chapter in one volume of the Technical Guide for Engineers and Builders [14].

Chimney reservoirs have been dealt with more extensively in international literature, foremost in the 


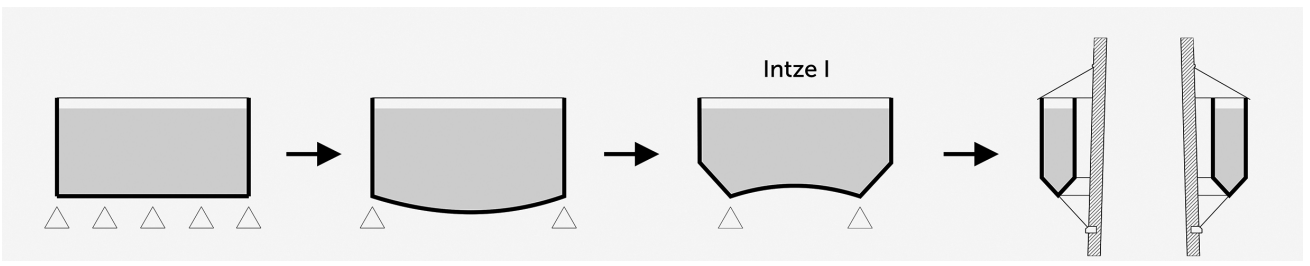

FIGURE 1. The evolution of the shape of the cylindrical tank - from a flat base to the chimney tank.

professional handbook series Handbuch für Eisenbetonbau, in particular, in the 1907 and 1934 editions [15, 16] and also in the professional lexicon authored by Franz Raul [17. Mentions of individual structures have also appeared in the journal Beton u. Eisen.

\section{Methods}

This paper is based on research that began by identifying and localising chimney reservoirs that were built on the territory of the Czech Republic. To this end, the authors drew on the findings of their own long-term private research in which they have identified (and created a database of) almost all the chimney reservoirs still standing in the Czech Republic and some that have been lost. This database has been updated and extended to include information on other chimneys no longer standing. This work was performed primarily by studying available illustrated documents (for example, materials available in the online Industrial Heritage Register of the Czech Technical University's Research Centre for Industrial Heritage FA CTU Prague) and by conducting a literature search through journals from the industrial era. The locations of chimneys now lost were identified with the aid of orthophotomaps from the 1950s (www.kontaminace.cenia.cz) and some original site plans of industrial enterprises that have been preserved to the present day.

The owners of the still existing chimney reservoirs were then approached with a request for permission to carry out a structural-historical research. This was done in order to capture each chimney's technical design and the current condition of the structure, create a photo-documentation of the site, investigate the wider context of the site, study the original technology and conduct a land survey, from which it was then possible to create a structural documentation of the current state of the chimney.

After all these research tasks carried out on site were completed, the authors searched archives and collections and the offices of relevant municipal authorities around the Czech Republic. The research also crucially involved a literature search through journals and ordinary printed matter from the relevant time period, interesting and valuable resources were found especially in digital libraries, such as Kramerius, the National Library of the Czech Republic, K4 of the National Technical Library and the Internet Archive. Some pieces of information were also obtained from living witnesses.

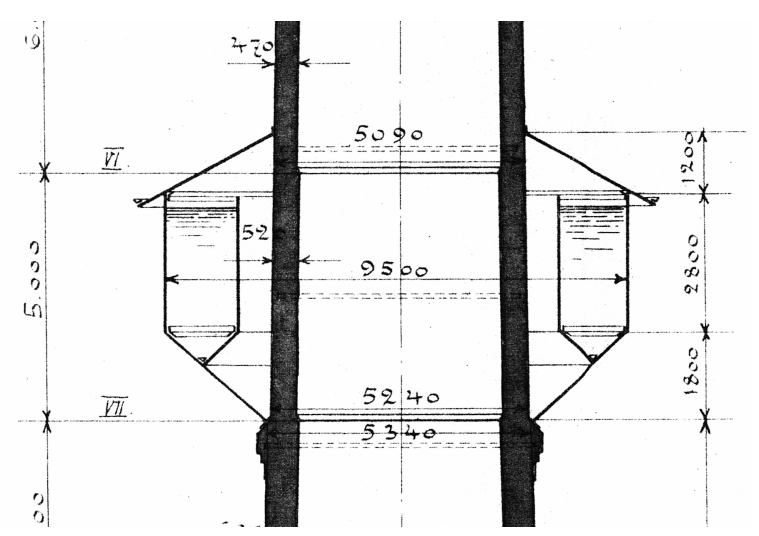

FIGURE 2. An Intze-type tank with a capacity of 100 $\mathrm{m}^{3}$ on the chimney of the Triumph factory in Netolice (design by H. R. Heinicke), 1905 [19].

\section{Results}

\subsection{The EVOlution OF THE SHAPE OF THE WATER TANK AND THE ORIGIN OF THE CHIMNEY RESERVOIR}

In the early 1890s, Dr. Ing. Otto Intze, a professor of construction and water resources management at the Royal Technical University in Aachen, came up with the idea of modifying the shape of the base in cylindrical water tanks by giving them an upwards concave shape, which, at the place where the tank is mounted, would expediently diminish the unfavourable effects of tangential forces. The result was a more delicate, lighter model of tank than the earlier version, in which the base bulged outwards and since the tank protruded from the support structure, it was possible to use a lighter, and therefore less expensive support structure for the tank tower. While one disadvantage cited was that the design was architecturally unsightly, given how the tank was visibly wider than the slender support structure of the tower, Intze's tanks, called the Intze I type, came to be very widespread, and Intze had his invention patented on 4 February 1883 [18], see Figures 1 and 2 .

The structural universality of the Intze I type meant that it could even be mounted on a chimney. This proved to be a more economical solution for smallersized tanks than building a new water tower. Another advantage was the fact that there was no need for the chimney supporting the water tank to be significantly different from any ordinary chimney (and it did not have to be more expensive because of the tank). At most it was necessary to reinforce the brickwork 


\begin{tabular}{cllr}
\hline $\begin{array}{c}\text { Year of the tank's } \\
\text { construction }\end{array}$ & Type of factory & \multicolumn{1}{c}{ Municipality } & $\begin{array}{c}\text { Tank } \\
\text { capacity }\end{array}$ \\
\hline $1907^{*}$ & paper mill & Olšany & $45 \mathrm{~m}^{3}$ \\
1908 & flax and cotton mill & Sudkov & $35 \mathrm{~m}^{3}$ \\
1910 & pipe mill & Ostrava - Svinov & $43 \mathrm{~m}^{3}$ \\
1912 & sugar refinery & Dobrovice & $35 \mathrm{~m}^{3}$ \\
1917 & railway workshops & Nymburk & $80 \mathrm{~m}^{3}$ \\
1917 & food production & Litovel & $35 \mathrm{~m}^{3}$ \\
1920 & mine & Vilémov - Zahořany & $20 \mathrm{~m}^{3}$ \\
1920 & glassworks & Rosice & $17 \mathrm{~m}^{3}$ \\
1921 & ironworks & Libčice nad Vltavou & $150 \mathrm{~m}^{3}$ \\
1922 & chemical plant & Kolín & $70 \mathrm{~m}^{3}$ \\
$1922-28$ & machine works & Slaný & $150 \mathrm{~m}^{3}$ \\
1929 & spinning mill & Choceň & $80 \mathrm{~m}^{3}$ \\
1930 & hospital & Pardubice & $25 \mathrm{~m}^{3}$ \\
1932 & armory & Přelouč & $55 \mathrm{~m}^{3}$ \\
1934 & warehouse & Prague - Vysočany & $50 \mathrm{~m}^{3}$ \\
1935 & prison & Prague - Ruzyně & $150 \mathrm{~m}^{3}$ \\
1941 & textile factory & Dvơr Králové nad Labem & $300 \mathrm{~m}^{3}$ \\
1942 & textile factory & Česká Skalice & $50 \mathrm{~m}^{3}$ \\
1947 & glassworks & Sázava & $50 \mathrm{~m}^{3}$ \\
1949 & chemical plant & Mělník & $35 \mathrm{~m}^{3}$ \\
1949 & machine works & Roudnice nad Labem & $65 \mathrm{~m}^{3}$ \\
\hline
\end{tabular}

* Chimney of the paper mill in Olšany was destroyed after finishing this article (in 2016).

TABLE 1. A list of chimneys with tanks that still exist.

beneath the tank to support the increase in load corresponding to the tank's capacity and small details were added to the shaft, such as ring supports and cornices. One of the main advantages of mounting a water tank on a chimney was that the warm gases expelled through the chimney helped prevent the water from freezing.

The increase in load caused by the addition of the tank produced concerns that the extra weight would exceed the load-bearing capacity of the chimney's brickwork. However, Intze did the statics calculations and demonstrated that not only were these concerns unwarranted, but, even taking into account the additional wind-loading effect caused by the presence of the tank and the greater surface area consequently exposed to wind, the use of this design actually increased the stability of the chimney.

\subsection{THE HISTORY OF CHIMNEY RESERVOIRS ON THE TERRITORY of The Czech RepubliC}

According to a current research, there is evidence that, in the past, 60 factory chimneys with chimney reservoirs were built on the territory of the Czech Republic, 38 of which have been demolished, while one has had its steel tank removed. This means that to date, just 21 such structures have survived, 19 of which have a reinforced concrete tank, one a brick tank, and one a steel Intze-type tank, see Figure 3 and Table 1

The first known chimney built with a steel tank was located on the site of Max Böhm and Co.'s mineral oil refinery in Přívoz. It was built before 1898. The last steel tank was built in 1917, in what was then Fryštát (today Karviná) on the site of Fryštát Steel and Iron Works Joint-Stock Company. The era of steel water tanks was, however, short-lived compared to that of reinforced concrete tanks.

The chimney with the largest known Intze tank was built in 1905 by the Viennese company L. Gussenbauer \& Sohn for the refinery of David Fanto and Co. in Pardubice. The chimney was 75 metres high (one of the tallest structures on the territory of the Czech Republic in its day) and it supported a tank with a capacity of $170 \mathrm{~m}^{3}$.

Two years later, G. A. Wayss \& Cie built the first reinforced concrete tank on the chimney of Olšany Paper Mill (Figure 8). The chimney was built by the Dresden-based company Vogel \& Köhler, which, a year later, built another chimney in nearby Sudkov, this time with a brick water tank. This is to date the only known and also the only standing chimney with a brick water tank in the Czech Republic.

The last existing steel tank in the Czech Republic built according to Intze's patented design is a reservoir with a capacity of $43 \mathrm{~m}^{3}$ that was installed on a chimney built in 1910 on the site of a former pipe mill in Ostrava - Svinov.

In the 1920s, the largest number of factory chimney reservoirs was built on the territory of the Czech lands. From this period, all 25 chimneys known to date had reinforced concrete tanks. 


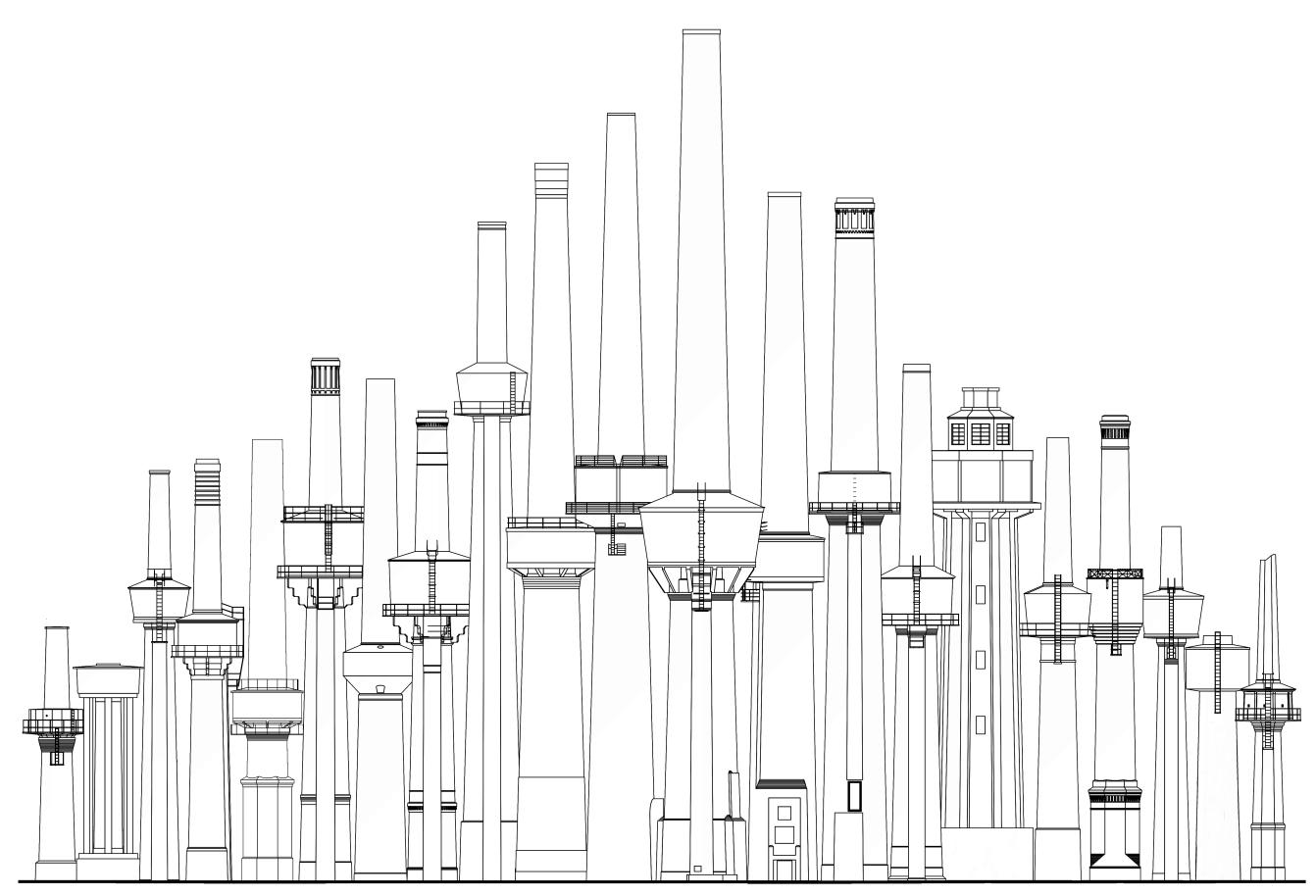

Figure 3. The last chimney reservoirs still standing on the territory of the Czech Republic.

A record-breaking chimney was built in the 1930s, the only chimney with a tank that reached a height of 100 metres. It stood on the grounds of the Incinerator of the City of Prague in Prague - Vysočany. The chimney, with a diameter of $450 \mathrm{~cm}$ at the top, built in 1932 by the renowned firm of V. Fischer and Co., supported a reservoir with a capacity of $200 \mathrm{~m}^{3}$.

The last chimney reservoirs were built in 1949 in Mělník and Roudnice nad Labem, no more were built after that, with one exception. The last reinforced concrete chimney built was 85 metres in height and was constructed for MAPE Mydlovary uranium-ore chemical preparation plant in 1961-1962 and it featured a reinforced concrete tank with a capacity of $200 \mathrm{~m}^{3}$.

There were several reasons why chimney reservoirs then ceased to be built and used. Because of the structure and the limited load-bearing capacity of chimneys, the size and the capacity of the tanks, and thereby their utility, were also limited. The advance of industry (especially heavy industry) after the Second World War in Czechoslovakia led to a proportional increase in the amount of water required by the industry. With the development of pumping technology, pumps became more powerful and there gradually ceased to be any need for highly elevated tanks to provide the necessary pressure to pump water through the system. And the introduction of new standardised types of mounted steel tanks was a great advantage for investors, because they were easy to install, the elevation of the tank could be adjusted, they were less expensive to build and they were relatively easy to maintain [20].

\subsection{The Structure AND MATERIAL OF CHIMNEY RESERVOIRS}

There are three generally known types of chimney reservoir distinguished by the material used in their design: steel, reinforced concrete and brick. Apart from the different primary material, the design of the reservoir, however, was roughly identical. These reservoirs were always built on a ring-shaped plan that could be mounted onto the shaft of the chimney. In steel reservoirs built according to the Intze principle, the walls of the tank formed concentric cylinders conically connected at their bases, while in reinforced concrete constructions, alongside the strictly cylindrically shaped reservoirs, there was also a frequently used alternative that had an inclined external wall, which gave the reservoir the shape of a truncated cone set on a narrower base. The main difference between the steel and the reinforced concrete varieties was in the shape of the base. While Intze reservoirs were conical, because this improved the statics of the structure, reinforced concrete reservoirs usually, but with some exceptions, had a flat base. Another difference was the position of the reservoir's inner wall: the steel variety kept a gap of at least $50 \mathrm{~cm}$ between the wall of the reservoir and that of the shaft to ensure an optimal function (this space prevented smoke expelled through the chimney from causing any significant increase in the temperature of the water, while at the same time the warm wall of the chimney was close enough to protect the water from freezing when outdoor temperatures were low in the winter months [21]); by contrast, the walls in the reinforced concrete version 
were located immediately adjacent to each other or with just a gap of several centimetres between them (Figure 4).

Chimney reservoirs were generally built with a capacity to hold between dozens and hundreds of cubic litres of water. The record-breaking reservoir in Europe was built on the chimney of a blast furnace plant in Essen-Borbeck (Germany) and was designed to hold $800 \mathrm{~m}^{3}$ [22]. The reservoir with the largest capacity ever built in the Czech Republic, $300 \mathrm{~m}^{3}$, was a reinforced concrete reservoir mounted on a chimney in Dvůr Králové nad Labem.

Steel reservoirs were made of pieces of sheet metal that were riveted together and were of a greater thickness, by roughly $5 \mathrm{~mm}$ or more, than what the statics calculations called for (in order to account for the risk of corrosion) [14. The reservoir structure was mounted on a stone or brick ring girder and the steel sections to which the reservoir structure was riveted were embedded into the girder.

Reinforced-concrete reservoirs could also be built either at the time of the chimney's construction or at any time while it was already working. Different forms of support could be used for the reservoir - for example, inlaid layers of bricks, a cornice, or with the aid of columns connected at the height of the reservoir by a circular girder. These methods of support were used from the very start when such reservoirs were built, and one of the first mentions of reservoirs supported by columns, brackets, or cornices on chimneys in the professional literature dates back to 1908 [23].

The most difficult task, however, was mounting a reservoir on a chimney already in operation - the warm shaft of the working chimney complicated the process. The heat in particular made it hard to apply the waterproof plaster. But it was possible to control, within bearable limits, how much the reservoir heated by inserting insulation in between the outer wall of the chimney and the wall of the reservoir.

The version that became most widespread on Czech territory used panels inserted into the brickwork of the chimney shaft to support the reservoir. The wall of the shaft, at the point where the reservoir was to be located, was expanded by adding bricks to create a space large enough for a reinforced-concrete floor. This floor, which in some cases was even used as a gallery around the reservoir, could also serve as the base of the reservoir, or the reservoir with a new base could be cemented into place separately onto this floor. When necessary the floor could be given reinforced support with the addition of brackets evenly distributed around the circumference of the shaft (numbering six, eight, or even more), locked together with a reinforced concrete ring (for example Dvưr Králové nad Labem, Prague - Vysočany - Prague City Incinerator and Českomoravská-Kolben-Daněk, a. s.). There were also cases where the brackets had no support function but were purely ornamental and intended to add a loftier appearance - for example, the chimney on the

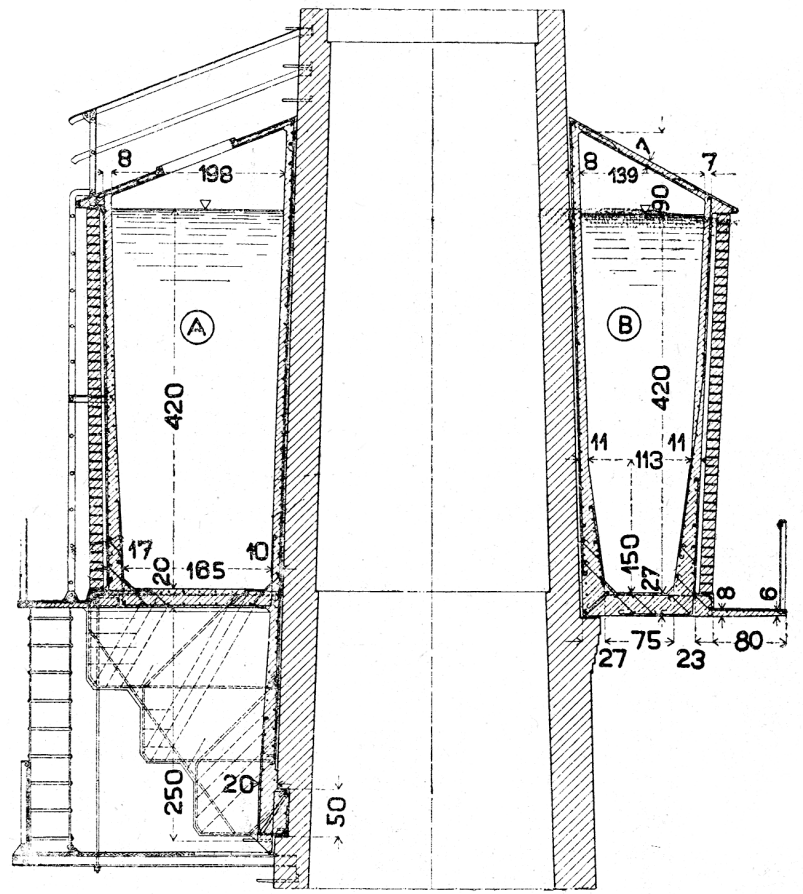

FiguRE 4. Standard design of a reinforced concrete chimney reservoir - on the left, the reservoir is supported with brackets, on the right, with a floor 14 .

site of Teerag joint-stock company in Hradec Králové and that on the site of F. Pánek Prague Screw Mill in Vysočany [13].

Similar installation methods were used to mount reinforced concrete reservoirs on already standing chimneys. One of the first known examples dates from 1905, at the site of a paper and cellulose plant in Gernsbach (Germany) [15. There are records of four in the Czech Republic. All the more valuable is the fact that two such examples in the Czech Republic are still standing, one in Libčice nad Vltavou (Figure 5 ) and one in Slaný (Figure 6). The two reservoirs, built in the $1920 \mathrm{~s}$, are structurally very similar and are identical in size $-150 \mathrm{~m}^{3}$. The supporting floor of the reservoir with a water column of up to 5 metres is supported by eight massive brackets or cantilevers set at an even distance from each other and with a total height of 2.5 metres.

A different technique was used to install brick reservoirs on a chimney shaft. In the past, the only brick reservoirs that could be found were ground reservoirs, the reservoirs of water towers were never made of bricks. In terms of material and technology, this is a rare form of design.

The walls of cylindrical chimney reservoirs were made of bricks and cement mortar and the strip steel was inserted into the bed joints. There is only one chimney with this reservoir design known to have existed on the Czech territory and it was built for the flax and cotton mill of Seidl Ignác and Co. in Sudkov (Figure 7). The reservoir has a capacity of $35 \mathrm{~m}^{3}$ and is supported by 16 steel I-beams arranged as brackets 


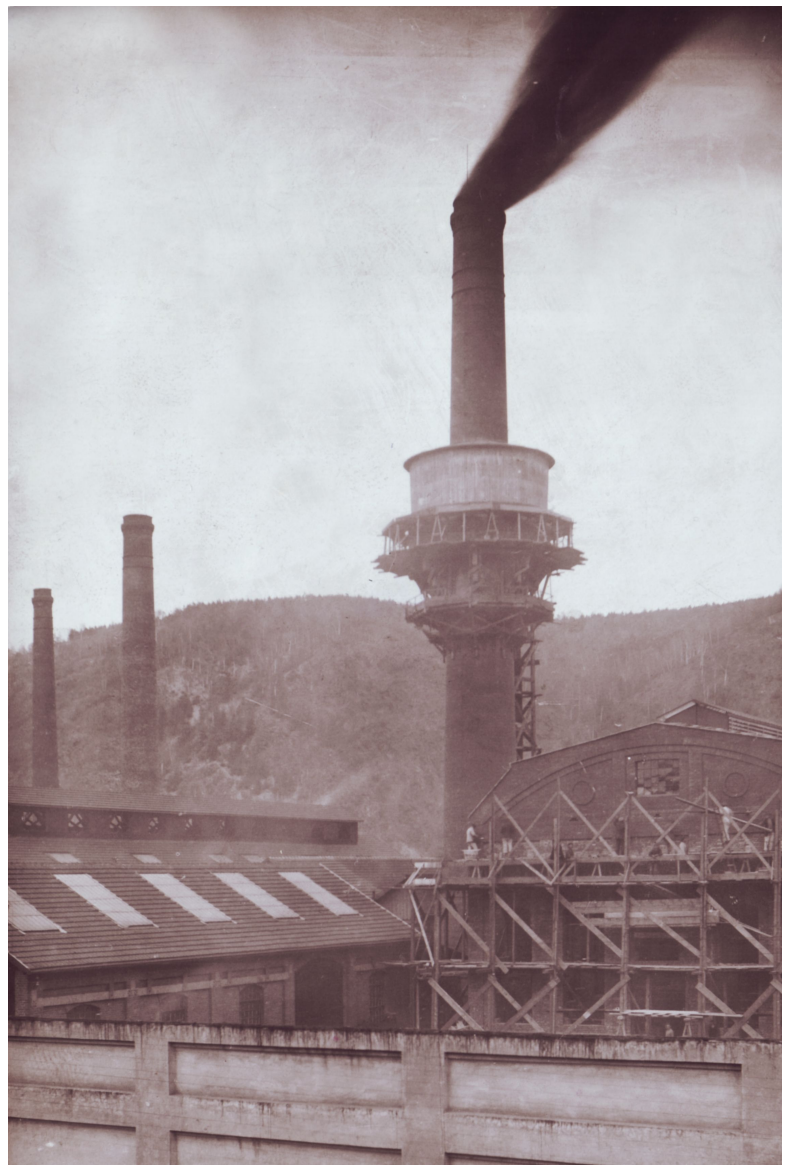

FiguRE 5. The construction of a reinforced concrete reservoir built onto a functioning chimney at the screw factory in Libčice, 1921 [24].

radiating out from the shaft of the chimney. These beams also support steel triangular frames and the almost two-metre-high space (created by this structure) beneath the base of the reservoir is filled with brickwork.

The reservoir had to be accessible from the outside and the inside and access also had to be provided for a worker to climb beyond the level of the reservoir up to the peak of the chimney. One commonly used solution to this that worked well was to install a small access floor beneath the base of the reservoir from which it was easy to reach the pipe valves (if they were mounted at this spot). In some cases, a ladder ran up through the reservoir, in which case a shaft large enough for a man to climb through distorted the even mass of the reservoir (Choceň, Pardubice, Olšany - Figure 8). This solution was frequently applied to Intze reservoirs - it was possible to move through the hollow space between the reservoir wall inside the chimney shaft and the outer face of the chimney.

Steel reservoirs were usually built without adding any thermal insulation or lining, while reinforced concrete reservoirs, apart for rare exceptions, usually had some form of insulation. In most cases, a brick facing was added to the outer reinforced concrete wall creating an air gap between the brickwork and the

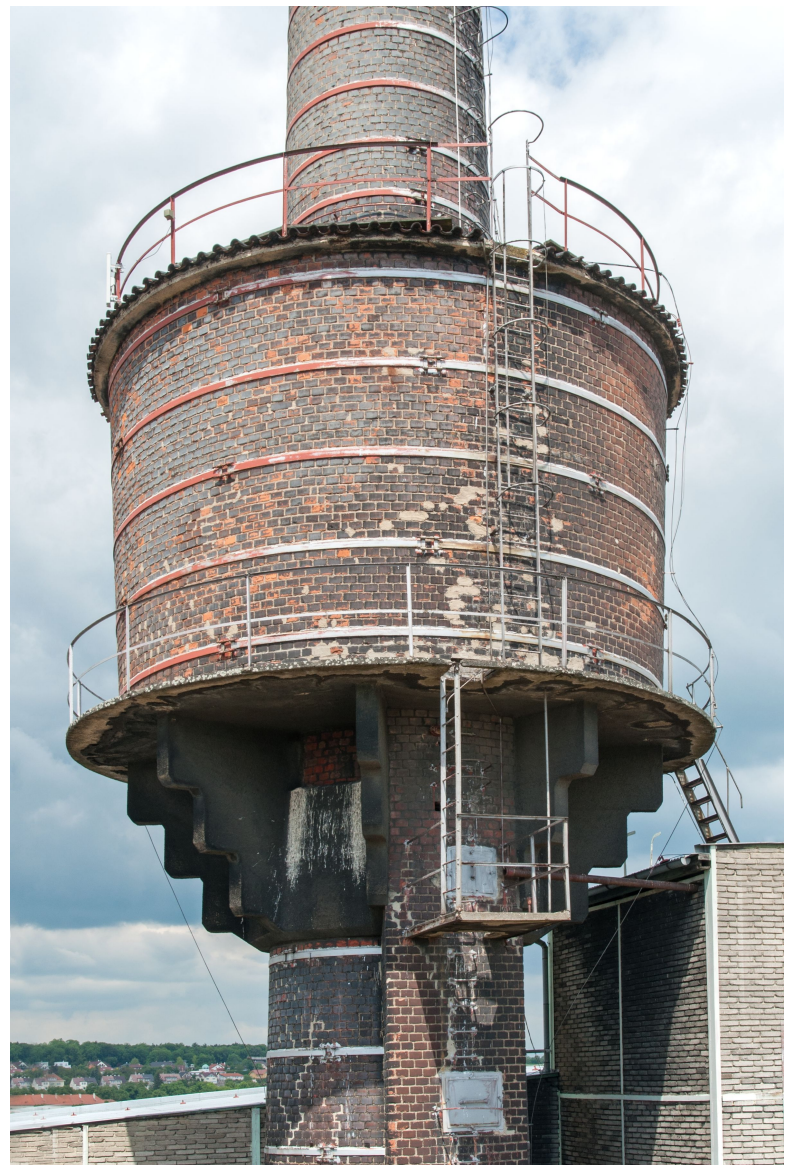

Figure 6. A reinforced concrete reservoir built onto a chimney in Slaný, 2013.

outer wall 5 to $8 \mathrm{~cm}$ thick. The facing was usually left as brickwork, but there are also examples where the surface was plastered, to which stucco decorations were sometimes even added (Vilémov - Zahořany).

The outer surface of the reservoirs was exposed almost always to the constant effect of water, which could be potentially damaging, especially to the reinforced concrete. While steel reservoirs were not waterproofed, appropriate measures had to be used to protect reinforced concrete reservoirs from this effect. If water penetrated the concrete and reached the steel reinforcement, it could lead to corrosion, which, in extreme cases, could render the structure unsafe. One of the priorities of the design and construction of the structure was to ensure it was impervious to the penetration of water from the outside (and that it was watertight in order to serve its function - to hold water).

In order to ensure that the reservoir remained watertight, it was essential to prevent the possibility of any cracks (even the smallest ones of no significance in terms of the stability of the structure) from forming in the structure. One way was to account for it in the design stage of the project, when the dimensions of individual parts of the structure affected by water pressure (the walls, the base) were being designed. Choosing the appropriate, good-quality concrete and 


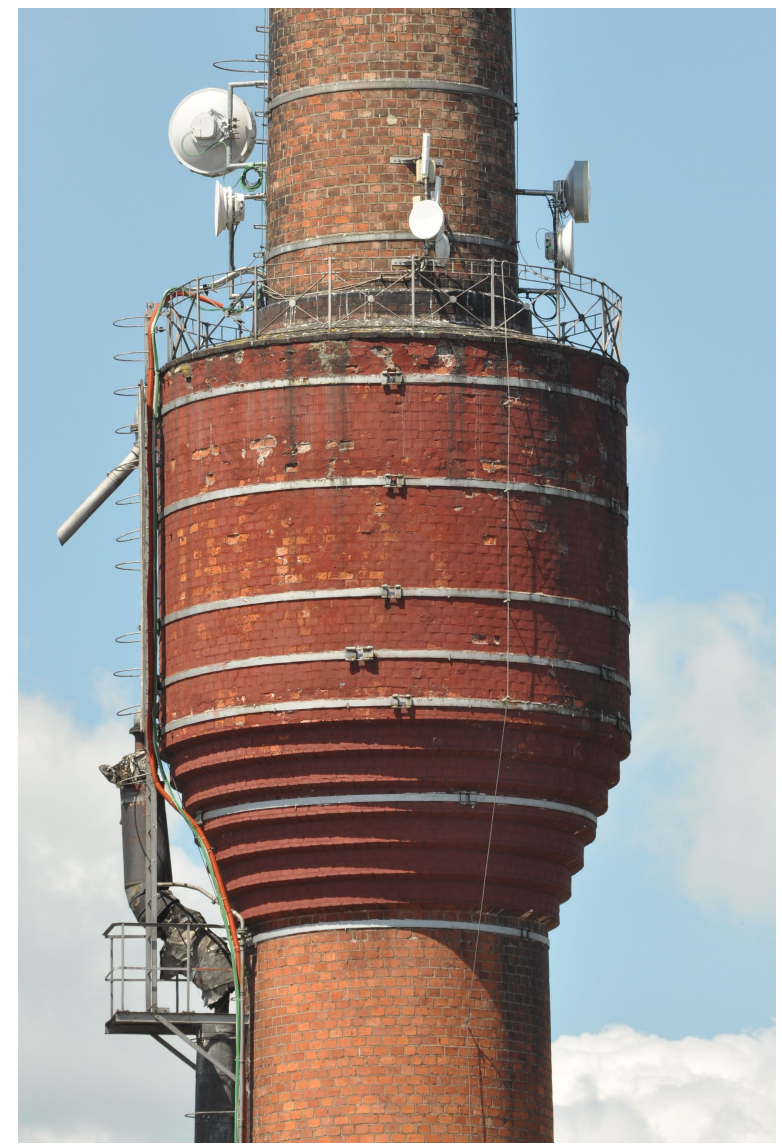

FiguRE 7 . The only known brickwork reservoir on the territory of the Czech Republic - the flax and cotton mill in Sudkov (built in 1908), 2015.

the right construction technology was also essential for the construction of a watertight structure. Cracks had to be prevented from occurring during the construction process as these could be a source of volume changes in the concrete caused by the contraction of the concrete or by alternations in temperature. It was also recommended that the height of the water column in the reservoir would be limited to 5 metres.

The use of cement plaster was the most common way of ensuring the reservoir structure remained watertight. It was applied in two or three layers to achieve a preferred total thickness of $15-20 \mathrm{~mm}$. It was essential to make sure that no cracks emerged in this process. Extra care also had to be devoted to any corners or sharp edges inside the reservoir - the transitions from the walls to the base were usually curved. This also helped to strengthen and create resistance to any tensile stress at these sections and they were also more amenable to the use of the cement plaster. Additional layers of waterproofing using asphalt or various types of insulating coatings could also be applied to the interior face of the reservoir.

\subsection{WATER-SUPPLY TECHNOLOGY}

Reservoirs mounted on chimneys were usually installed 20 to 35 metres above ground (measured up to the base of the reservoir). Of the chimney reservoirs still

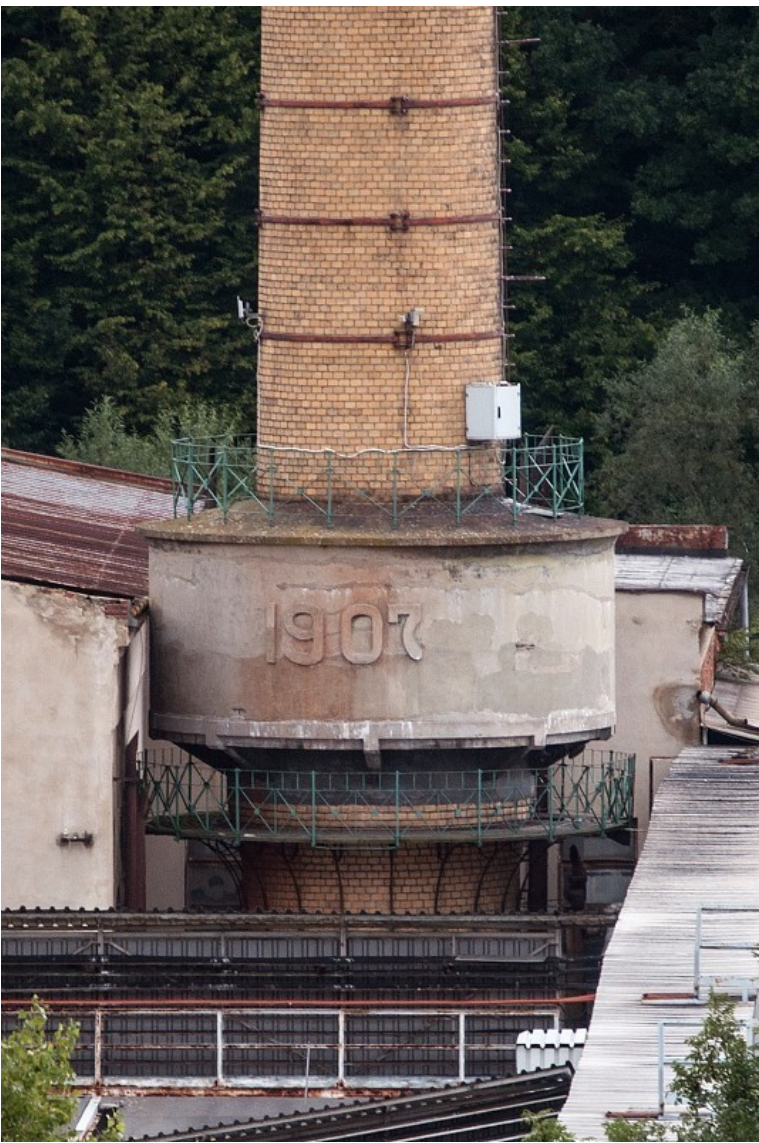

FiguRE 8. The first reinforced concrete chimney reservoir - the paper mill in Olšany (built in 1907, demolished in 2016), 2013.

standing, the one built closest to the ground is the reservoir in Rosice (14 metres above ground), and the one mounted highest is in Přelouč (at 45 metres above ground - Figure 9). The height at which the reservoir was placed along the length of the chimney always ultimately depended on what height was required to ensure the necessary level of pressure in the watersupply system.

Water pumped into the reservoirs could come from one of a number of sources. For the earliest structures, local wells, streams, and natural or artificial ponds or lakes were the most common sources in which the water accumulated from the source and then was pumped into the system (Ostrava - Svinov, Slaný, Vilémov - Zahořany). Some chimney reservoirs were also hooked up to the public water-supply network (Nymburk, Prague - Vysočany - Central Warehouse of the Ministry of Post and Telegraphs).

What the water was meant to be used for also differed from case to case and in many instances served various functions in the immediate area. It was used for steam boilers (Prague - Vysočany - Central Warehouse of the Ministry of the Post and Telegraphs, Kolín), in industrial production processes (Mělník cooling water, Litovel - washing water), as a drinking water or utility water used by employees (Slaný - bathrooms, showers, toilets, Pardubice - drinking 


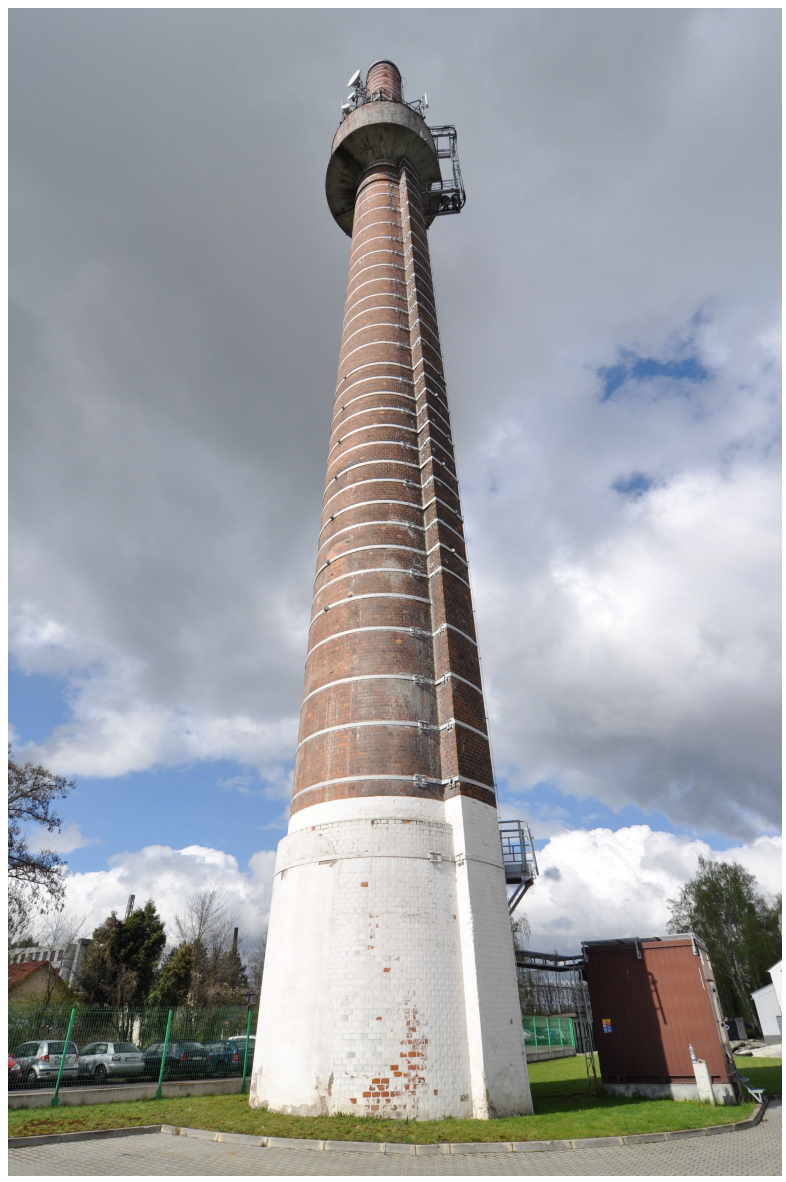

Figure 9. An example of a brick piping shaft, 2014.

water for the hospital grounds), and also as a water for fire extinction (Sudkov, Dobrovice, Choceň). In the latter case, the water reservoir was hooked up to a sprinkler system.

The reservoir was equipped with the necessary technological equipment - pipe systems (supply, draw-off, overflow and outlet pipes), valves and fixtures, systems for measuring the current level of water in the reservoir.

The number of pipes hooked up to the chimney reservoir also tended to vary, depending on what the water was to be used for, but in most cases, we find a system of two or three pipes connected to the reservoir.

When there were two pipes, one served as both the supply and draw-off pipe. Above the reservoir, this pipe sometimes branched into two parts - the top section served as the supply pipe and led into the tank above the overflow line (the water poured into the reservoir on top of the surface water in order to avoid stirring up sediment on the floor of the reservoir), while the bottom section served as the draw-off pipe and was usually fitted with a 'strainer'. When the pipe did not branch off into two sections, it always led into the reservoir at the bottom (Litovel). The second pipe, in some cases, also branched into two and did so below the tank (in this case we speak of an outfall pipe), and one section served the function of drawing water out of the overflow pipe and the other section of the outlet pipe (Nymburk). When the second pipe did not branch into sections, it served only as an overflow pipe. The two-pipe system was commonly used in the construction of water tanks in the 1920 s when the reservoirs were still being made of steel.

Several chimney reservoirs were hooked up to a three-pipe system, serving the functions of supply, draw-off, and overflow pipes (Prague - Vysočany) or one pipe served the function of a supply and draw-off in one while the other two were overflow and outlet pipes (Dvưr Králové nad Labem). An example of a well-preserved three-pipe system (supply, draw-off, and outfall pipes), where the outfall pipe then divides into two, an overflow and an outlet pipe, below the reservoir, can be found on the chimney reservoir of the chemical plant in Kolín.

The overflow pipe was used to safely drain water out of the tank if the water was still being pumped into the tank even though the maximum water level had been reached, which could occur if the pump switch was broken or as a result of negligence on the part of the staff operating the pump. The outlet pipe was used to drain all the water from the tank so that it could be cleaned and maintained. The draw-off pipe at the base of the tank was always located slightly higher than the outlet pipe in case there was a sedimentation of minute indissoluble materials in the water [11.

On some chimney reservoirs, the overflow pipe led out of the reservoir into the open, so if the water overflowed it fell straight out of the reservoir onto the ground (Ostrava - Svinov, Sudkov).

There were two techniques used to install the pipe system onto the chimney structure. The oldest approach was to install the pipes along the outside of the chimney shaft. This method was used on the very first chimney reservoirs in Germany and it required that the pipes be thoroughly insulated to prevent the water from freezing. Moulded quadrantal bricks of crushed cork bonded with asphalt or some other emulsion were used as effective insulation materials and the pipes were lined with them. The bricks were secured in place with wire or strip steel. Pipes with this kind of insulation were wrapped in a tar paper or sheet metal. The piping on the chimney in Ostrava Svinov has an insulation made of wood wool twisted into cords beneath the steel covering.

There is one known case where the piping was not installed against the wall of the chimney structure but was hung from steel sections bracketed onto the shaft (Vilémov - Zahořany).

In later versions, a brick shaft was built onto the outer wall of the chimney shaft and the piping ran up through the inside of the brick structure, which provided a sufficient protection against the water freezing in the system (the first known example of the use of this brick shaft on Czech territory can be found on the chimney of the sugar refinery in Dobrovice). All the still standing chimneys with a water reservoir 


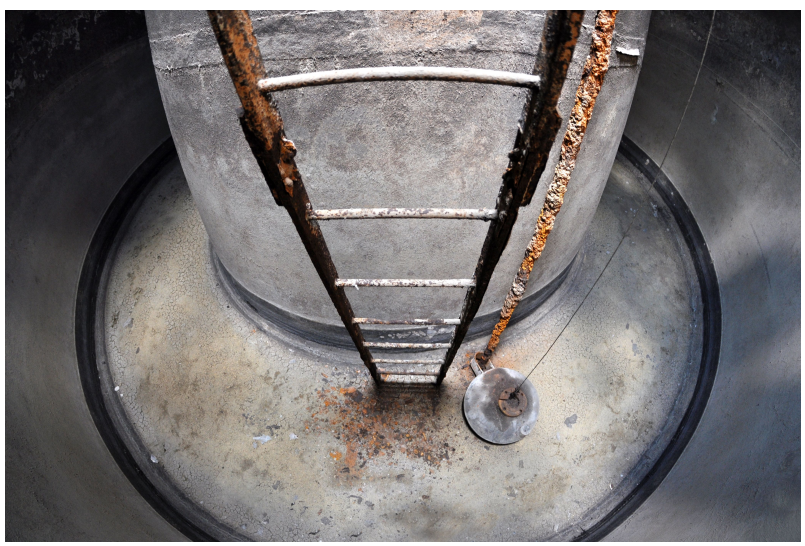

Figure 10. The inside of a chimney reservoir with a float gauge in Slaný, 2013.

that were built by the Fischer company, except the chimney in Nymburk, have this kind of brick shaft that houses the pipes.

An interesting technique that distinctively affected the appearance of the chimney reservoirs as a whole was to install the piping in three free-standing columns or four separate shafts running up the side of the chimney shaft. These techniques are commonly found on the chimney reservoirs built by Ing. Josef Jaroslav Hukal and Co. A chimney with these shafts can still be found today on the grounds of a hospital in the town of Pardubice and in the past there was also one on the grounds of a hospital in České Budějovice.

The volume of water in the reservoir had to be monitored with a system that could check the level of water in the tank. The process of refilling the reservoir needed to be carefully monitored, especially in cases where the reservoir served as the source of water to extinguish fires and as a source of pressure required in the system.

In the earliest chimney reservoirs, the level of water in the tank was monitored with a level gauge, which could be installed directly on the outer casing of the tank or on the lower sections of the chimney. Only several level gauges have survived to the present day. The gauges were in the form of two pieces of wood boards with the water-level indicator enclosed between them (Sudkov) or a similar model made of metal (Nymburk, Slaný - Figure 10. The actual level of water was transmitted by means of a mechanism consisting of a float, a steel-wire rope and a guide pulley.

In later years, these early mechanisms were replaced with more modern systems (Mělník - a resistance gauge that measures the level of the water, Dívčice remote gauges that electrically transmit data through an electric current).

\section{Conclusion - the Future OF CHIMNEY RESERVOIRS}

Among the chimney reservoirs that are still standing in the Czech Republic, only one is still fully in operation and it is in Mělník (Mefrit, spol. s r.o.). The chimney vents flue gases from the furnaces in the plant and water in the reservoir is used for industrial purposes. In some cases, even though the chimneys are no longer in operation, the reservoirs are still in use - for example, the chimney reservoir on the grounds of what was originally Alibona Litovel and is now Alibona a.s. (to wash raw vegetables) and the one on the grounds of a screw factory in Libčice now called SCREWS \& WIRE Libčice a.s. (water from the Vltava River is used here for industrial purposes). The other chimney reservoirs still standing are no longer in operation and they are gradually falling to ruin, so the question of what is to become of them needs to be addressed urgently.

A positive example of a chimney reservoir conservation is provided by the chimney in Vilémov - Zahořany. It has been preserved there to stand as a symbolic reminder of the mining industry that existed in the region, after all the other buildings connected to the operations of Prokop Mine were demolished in 2012.

Chimneys are now also widely used by telecommunications operators and wireless data services providers who mount antennae and transmitters on their peaks (for example Choceň, Slaný, Pardubice). This new, albeit not very attractive, use grants a security for some of these structures that they will continue to exist in the years to come, as these chimneys generate income for the repairs and maintenance they need. At the hospital in Pardubice, the chimney is moreover covered with ivy, which is a welcome and aesthetically fitting feature in this location.

The research also included designing new use for chimney reservoirs that are no longer in use. However, that issue is not the subject of this article.

\section{ACKNOWLEDGEMENTS}

This paper was prepared with the financial support of the Ministry of Culture of the Czech Republic as part of the NAKI applied research programme - DF13P01OVV021.

\section{REFERENCES}

[1] J. Douet (ed.). Industrial heritage re-tooled: the TICCIH guide to industrial heritage conservation, Lancaster: Carnegie Publishing Ltd., 2012.

[2] M. Stratton (ed.). Industrial buildings: conservation and regeneration, London, 2000.

[3] B. Fragner, V. Valchářová (eds.). Industrial topography - the architecture of conversion: Czech Republic 2005-2015, Praha, 2014.

[4] E. Dvořáková, B. Fragner, T. Šenberger. Industriál pamět - východiska: nové funkčni využiváni uvolněných objektů, Praha, 2007.

[5] J. Douet. Going up in smoke, Victorian Society, 1989.

[6] G. L. Patiño, A. M. Boquera, L. M. Aznar. Chimeneas industriales de ladrillo helicoidales. In Actas del Séptimo Congreso Nacional de Historia de la Construcción, Madrid, 2011.

[7] M. Vonka. Tovární komíny. Funkce, konstrukce, architektura, Praha, 2014. 
[8] J. Jásek, J. Beneš. Pražské vodní věže, Praha, 2000.

[9] J. Jásek. Nekrolog pražský komínových vodojemů. In SOVAK - Sdružení oboru vodovodi̊ a kanalizací XIV, No. 1, Praha, 2005, pp. 26-27.

[10] F. Klokner. O továrních komínech, Praha, 1906.

[11] J. V. Hráský. Přednášky o vodárenství. (Zásobování měst a krajin vodou.), Část II., Vodojmy, Praha, 1919, pp. 120-130.

[12] K. Válek. Statické řešení válcové stěny. In Technický obzor XXIX, No. 27, Praha, 1921, pp. 129-131.

[13] R. Kukač. Železobetonové reservoiry na továrních komínech. In Zprávy veřejné služby technické II, No. 10, Praha, 1920, pp. 243-244.

[14] A. Klír, F. Klokner (eds.). Technický průvodce pro inženýry a stavitele. Sešit sedmý. Stavitelství vodní, II. část. Vodárenství, Praha, 1923, pp. 134-135.

[15] F. E. Emperger. Handbuch für Eisenbetonbau in vier Bänden, Dritter Band, Berlin, 1907, pp. 452-454.

[16] F. E. Emperger. Handbuch für Eisenbetonbau in vierzehn Bänden, Neunter Band, Berlin, 1934.
[17] F. Rauls. Lexikon des Schornsteinbaues und der Reparaturen, Cöln, 1906.

[18] Hochreservoir von Otto Intze in Aachen. In Dinglers polytechnisches Journal, Band 249, 1883, pp. 485-486.

[19] State archive SOkA Prachatice.

[20] R. Kořínek. Vodárenské věže. 4. část: Soumrak elegance vodárenských věží a cesta do současnosti. In SOVAK - Sdružení oboru vodovodů a kanalizací XXII, No. 6, Praha, 2013, pp. 16-17.

[21] Wasserbehälter auf dem Schornstein. In Dinglers polytechnisches Journal LXXV, No. 8, 1894, pp. 191.

[22] E. Ackermann. Das Hochofenwerk der Fried. Krupp A.-G. in Essen-Borbeck. In Der Stahlbau IV, No. 9, 1931, pp. 104-105.

[23] M. Strukel. Der Wasserbau für studierende und praktiker, zweite Auflage, Leipzig, 1908, pp. 144.

[24] Archive CTU in Prague. 